\title{
GMR
}

\section{Photosynthesis enhanced oxidative stress tolerance in high-yield rice varieties (Oryza sativa var. japonica L.) in the field}

\author{
X.D. Wei*, L. Jin* and X. Li \\ Institute of Food Crops, Jiangsu Academy of Agricultural Sciences, \\ Jiangsu High-Quality Rice R\&D Center, Nanjing Branch, \\ China National Center for Rice Improvement, Nanjing, China \\ *These authors contributed equally to this study. \\ Corresponding author: X. Li \\ E-mail: weiyinglin@163.com
}

Genet. Mol. Res. 15 (3): gmr.15038247

Received December 10, 2015

Accepted February 11, 2016

Published July 29, 2016

DOI http://dx.doi.org/10.4238/gmr.15038247

Copyright (C) 2016 The Authors. This is an open-access article distributed under the terms of the Creative Commons Attribution ShareAlike (CC BY-SA) 4.0 License.

ABSTRACT. The objective of this study was to understand varietal
differences in photosynthetic characteristics, chlorophyll fluorescence,
antioxidant capability, and yield of japonica rice varieties. Nanjing 44 ,
Oryza sativa var. japonica (average yield of $12.7 \mathrm{t} / \mathrm{ha}$ ), Nanjing 46 ,
and Nanjing 5055 (average yields of 11.3 and $11.5 \mathrm{t} / \mathrm{ha}$ ) were included
as "super" and high-yield varieties, respectively, whereas Wuyunjing
7 (average yield of $10.2 \mathrm{t} / \mathrm{ha}$ ) was included as a control variety. These
varieties were grown under field conditions in Jiangsu Province,
China, in 2010-2012. Different organs (panicle, grain, etc.) were
measured, before and after flowering, to identify differences of dry
matter accumulation and transformation properties. Photosynthesis, the
chlorophyll content, and antioxidant enzyme activities of the flag leaf
in the days after flowering (DAF) were also investigated. The results 
showed that, compared with the other three rice varieties, Nanjing 44 had the highest plant dry weight and number of grains per panicle. It also had a relatively high net flag leaf photosynthetic rate and showed the least inhibition of photosynthesis at noon in DAF, which probably explains the higher yield in this variety. Furthermore, Nanjing 44 also had the highest stem export and conversion rate from stem to grain, exhibiting a strong ability to convert and distribute photosynthetic products. After DAF 42, Nanjing 44 still maintained a high-soluble protein content and a high antioxidant ability in the leaves to clear peroxidation products, which could protect the photosynthetic apparatus of the flag leaves, and maintain the grain-filling activity for longer. The high-yield capability of Nanjing 44 was attributed to its photosynthetic advantages in the leaves during the late developmental stage.

Key words: Rice (Oryza sativa var. japonica L.); Photooxidation; Net photosynthetic rate; Yield component; Antioxidant enzyme

\section{INTRODUCTION}

To satisfy population growth and economic development requirements, a required increase in global average food yields by more than $1.2 \%$ per year was suggested by Normile (2008). To achieve this goal, great efforts should be made to breed new rice varieties using new planting patterns with higher yield potentials, to enhance average farm yields (San-oh et al., 2006; Peng et al., 2008). The development of semi-dwarf varieties in the late 1950s in China and in the early 1960s at the International Rice Research Institute, dramatically increased the yield potential of irrigated rice. The yield potential was further increased by the development of hybrid rice in 1976. China has been successful in breeding hybrid rice strains, but is now facing challenges to develop new hybrids with high-yielding potential, better grain quality, and tolerance to biotic and abiotic stresses (Cheng et al., 2007; Tester and Langridge, 2010).

Yield potential is defined as the yield of a variety when grown in environments to which it is adapted (Evans, 1993). In China, a nationwide mega-project on the development of modern rice (Oryza sativa L.) cultivars, especially the newly bred "super" rice based on the ideotype concept, has been established trying to combine the ideotype approach with the use of intersubspecific heterosis (Xiao et al., 1996; Yuan, 2001). Green Super Rice should possess resistance to multiple insects and diseases, high nutrient efficiency, and drought resistance, promising to greatly reduce the consumption of pesticides, chemical fertilizers, and water (Kato et al., 2004; Zhang, 2007). "Super" rice varieties have numerous spikes per panicle resulting in a larger yield capacity. It was reported that by 2010, the Chinese Ministry of Agriculture had released 80 varieties of "super" rice varieties, including inbred indica, japonica, and hybrid rice varieties (Wu et al., 2010). Under field conditions, it was found that many "super" rice varieties could not reach their yield potential with lower grain-filling rate, because they were not adapted to the changing environment (Yang and Zhang, 2010; Li et al., 2010b).

Although there has been much research on "super" rice varieties, previous studies have mostly focused on the "super" hybrid rice (Li et al., 2010a) or "super" rice varieties in the north of China ( $\mathrm{Li}$ and Han 2010). These studies were mostly interested in the morphological and filling characteristics of rice under different cultivation conditions, such as alternate

Genetics and Molecular Research 15 (3): gmr.15038247 
wetting and drying, irrigation, or nitrogen levels (Peng et al., 1999; Yang et al., 2002; Mishra and Salokhe, 2008; Zhang et al., 2009a, 2012). Understanding the regulation of grain filling in the field is important for improving rice yield potential (Murchie et al., 2002).

The rice varieties from the Jiangsu Province often suffer different climate conditions, such as continuous rain (low light intensity), the first sunny day (high light intensity) after the continuous rain, a hot late-growth stage without water (water shortage), as well as other stress conditions during the whole growth stage ( $\mathrm{Li}$ et al., 2010c). Currently, 10 rice varieties that met the "super" rice criteria were released by the Jiangsu Province. Of these, eight varieties belong to the japonica rice (China National Rice Research Institute and the National Rice R\&D Center Industrial Technology, 2010). The "super" japonica rice criteria in China are that the japonica rice variety can get more than 11.7 tons per hectare in two consecutive years in the field. How these "super" japonica rice varieties are able to survive so many stresses during the life time, while, at the same time, exhibit a high-grain-filling rate, producing high yields, is yet to be understood.

In this paper, four japonica rice varieties with different yield levels from the Jiangsu Province in China were used in the days after flowering (DAF) in field conditions over 3 years. The objectives of this study were to understand the material accumulation, photosynthetic characteristics, and operation of varietal difference during DAF in the field.

\section{MATERIAL AND METHODS}

\section{Experimental site}

Experiments were conducted in the field at the Jiangsu Academy of Agricultural Sciences, Nanjing city, Jiangsu Province, China $\left(32^{\circ} 02 \mathrm{~N}, 118^{\circ} 52 \mathrm{E}, 11 \mathrm{~m}\right.$ a.s.l.) on a brunisolic soil (Alfisols, USA). The rice-cropping system has prevailed in this region for more than 1000 years, and represents the typical cropping system in Asia. The relevant soil properties were as follows: total $\mathrm{N}=2.52 \mathrm{~g} / \mathrm{kg}$, total $\mathrm{P}=0.60 \mathrm{~g} / \mathrm{kg}$, total $\mathrm{K}=14.0 \mathrm{~g} / \mathrm{kg}$, available $\mathrm{P}=166.22$ $\mathrm{mg} / \mathrm{kg}$, available $\mathrm{K}=165.03 \mathrm{mg} / \mathrm{kg}$, and soil organic $\mathrm{C}=8.24 \mathrm{~g} / \mathrm{kg}$. The climate conditions are humid subtropical monsoon with a mean annual precipitation of $1050 \mathrm{~mm}$, mean annual temperature of $16.7^{\circ} \mathrm{C}, 1900 \mathrm{~h}$ annual sunshine time, and a frostless period of 237 days.

\section{Crop management}

Four rice varieties (Oryza sativa var.japonica), Nanjing 5055, Nanjing 44, Wuyunjing 7, and Nanjing 46, were tested in this experiment conducted in 2010-2012. Nanjing 44, which has an average yield of $12.7 \mathrm{t} / \mathrm{ha}$, was included as a "super" rice variety type. Nanjing 46 and Nanjing 5055, having average yields of 11.3 and $11.5 \mathrm{t} / \mathrm{ha}$, were considered intermediate yield types. Finally, Wuyunjing 7 has an average yield of $10.2 \mathrm{t} / \mathrm{ha}$, which is considered a low-yield type and was included in our study as a control variety. The sources of the varieties are listed in Table 1. The rice seeds were sterilized with an antiseptic and then soaked for 72 $\mathrm{h}$ to germinate. On May 16 of each year, the soaked seeds were directly sown in the seedbed and kept moist. Rice seedlings were transplanted manually into their corresponding field plots in mid-June with a hill space of $0.167 \times 0.200 \mathrm{~m}$. Rice plants were harvested in October, depending on the maturity dates of each plot. The N, P, and K fertilizers of each plot were 374, 187 , and $187 \mathrm{~kg} /$ ha, respectively. $\mathrm{P}, \mathrm{K}$, and $50 \%$ of N, were applied as a basal dressing 2 days

Genetics and Molecular Research 15 (3): gmr.15038247 
prior to transplanting. Half of the remaining $\mathrm{N}(25 \%)$ was applied as a side dressing at early tillering in the latter half of June and the other half was applied at panicle initiation in the latter half of August each year.

Table 1. Information about the japonica rice varieties used in the experiment.

\begin{tabular}{|c|c|c|c|c|c|}
\hline Group & Variety & Subspecies type & Year of release & Female parent & Male parent \\
\hline Inbred (CK) & Wuyunjing 7 & \multirow[t]{4}{*}{ japonica } & 1996 & Jia 48/Xiangnuo9121 & Bing 815 \\
\hline "Super" japonica & Nanjing 44 & & 2004 & $45115-2 / \mathrm{R} 405$ & NJ30125 \\
\hline \multirow[t]{2}{*}{ Ordinary hybrids of good quality } & Nanjing 46 & & 2008 & Wuxiangjing 14 & Guandong 194 \\
\hline & Nanjing 5055 & & 2005 & Wujing 13 & Guandong 194 \\
\hline
\end{tabular}

CK stands for a control variety with low yield in the present study.

According to the method of Yang et al. (2000), panicles that headed on the second day from the onset of heading were selected and tagged. The heading period was 7 days for a line or cultivar $(90 \pm 10 \%$ panicles headed). A consequence of this was that the panicles sampled were mostly from main stems (approximately 70\%) and the remainder from primary tillers (approximately 30\%). Previous data showed no significant differences between the main stem and primary tiller in either final panicle weight or the timing or rate of grain filling within a line or cultivar if their panicles headed on the same day. Only tagged tillers were used for measurements of photosynthesis, sample collection $\left(1 \mathrm{~cm}^{2}\right.$ leaf disc per sample), and panicle dry weight (DW). On each tiller, one measurement of photosynthesis was made (in the morning) and leaf discs for protein and chlorophyll (Chl) content analysis were cut from that same tiller and immediately frozen in liquid $\mathrm{N}_{2}$. Three of the panicles were then removed for immediate assay of DW. Panicles were dried at $70^{\circ} \mathrm{C}$ and weighed at 2-day intervals until the weight did not change. Yield components were determined as described by Li et al. (2011).

\section{Screening for tolerance to photooxidation}

Screening for tolerance to photooxidation was determined, as described by Jiao and $\mathrm{Li}$ (2001). Photooxidation treatments were also conducted at the booting stage. Five detached mature leaves from rice plants that were grown under natural light conditions were cut and placed on a white tray $(23 \mathrm{~cm}$ long, $17 \mathrm{~cm}$ wide) with a $2.5 \mathrm{~cm}$ depth of water containing equilibrated ambient levels of $\mathrm{CO}_{2}$ and $\mathrm{O}_{2}$. After $2 \mathrm{~h}$, the $\mathrm{O}_{2}$ concentration was increased to about $266 \mu \mathrm{M}$ and the $\mathrm{CO}_{2}$ concentration was decreased to minimum levels $(0.75 \mu \mathrm{mol})$ because of leaf photosynthesis. Leaf blades were kept immersed and flat by an overlaid transparent glass plate, thus providing continuous exposure to natural sunlight. The water temperature was equilibrated with the air temperature during the day (maximum temperature $35^{\circ} \mathrm{C}$ ) and night (average $25^{\circ} \mathrm{C}$ ). Tolerance to photooxidation was determined by the degree of decline in Chl content and a visible score of leaf color after 6 days.

\section{Determination of the Chl content}

Five full-exhibition features of the leaves were measured during rice booting. The Chl content was determined using dimethyl sulfoxide (DMSO) as extraction solvent (Lichtenthaler and Wellburn, 1983). Plant materials were extracted at $60^{\circ} \mathrm{C}$ for $2 \mathrm{~h}$, the temperature was maintained by a water bath with a thermostat, and light was kept out by wrapping the sample

Genetics and Molecular Research 15 (3): gmr.15038247 
in aluminum foil. The samples were stored in the dark until all greenish remnants had been extracted by the DMSO solution. The supernatant was decanted and the absorbance was read at wavelengths of 480, 665, and $649 \mathrm{~nm}$ using a UV-Vis spectrophotometer UV-2550 (Shimadzu Corporation, Kyoto, Japan).

\section{Net photosynthetic rate $\left(P_{n}\right)$}

The $P_{n}$ of intact rice leaves was monitored with a Li-Cor 6400 portable photosynthesis system (Lincoln, NE, USA) according to the method of Li et al. (2010c). The gas source was compressed air with a $\mathrm{CO}_{2}$ concentration of $350 \mu \mathrm{mol} / \mathrm{mol}$. The measurements were made between 9:00 and 11:00 am. Red and blue sources under the open system were used to take measurements under the following conditions: $800 \mu \mathrm{mol} \cdot \mathrm{m}^{-2} \cdot \mathrm{s}^{-1}$ photosynthetic photon flux density, $500 \mu \mathrm{mol} / \mathrm{s}$ flow rate, and $30^{\circ} \mathrm{C}$ leaf chamber temperature. In each treatment, the first leaves under the tassel (the three youngest) were used for the measurements, and each leaf was measured five times.

\section{Malondialdehyde (MDA) content}

MDA content was measured according to the method of Sofo et al. (2004), with minor changes. In summary, $1 \mathrm{~g}$ leaves was homogenized in $10.0 \mathrm{~mL} \mathrm{10 \%} \mathrm{(w/v)} \mathrm{trichloroacetic} \mathrm{acid}$ and was centrifuged at $10,000 \mathrm{~g}$ for $5 \mathrm{~min}$. A $2-\mathrm{mL}$ aliquot of supernatant was added to $2.0 \mathrm{~mL}$ $0.6 \%(\mathrm{w} / \mathrm{v})$ thiobarbituric acid in $10 \%(\mathrm{w} / \mathrm{v})$ trichloroacetic acid. The mixture was heated to $100^{\circ} \mathrm{C}$ for $15 \mathrm{~min}$ and then rapidly cooled in an ice bath. After centrifugation at $10,000 \mathrm{~g}$ for 10 min, the absorbance values at 532, 600, and $450 \mathrm{~nm}\left(\mathrm{~A}_{532}, \mathrm{~A}_{600}\right.$, and $\left.\mathrm{A}_{450}\right)$ of the supernatant were recorded. The value for nonspecific absorption at $600 \mathrm{~nm}$ was subtracted, and a standard curve for sucrose (from 2.5 to $10 \mu \mathrm{mol} / \mathrm{mL}$ ) was used to rectify the results from interference of soluble sugars in the samples (at $\mathrm{A}_{532}$ and $\mathrm{A}_{450}$ ). The MDA content was calculated from the absorption coefficient of $157 \mathrm{mmol} / \mathrm{cm}$ and was expressed as nmol MDA/mg (protein).

\section{Activities of antioxidant enzymes}

Determination of the activity of antioxidant enzymes and concentration of related metabolites was undertaken according to optimized protocols described previously (Habibi et al., 2010). Fresh samples were ground in the presence of liquid $\mathrm{N}_{2}$ and measurements were undertaken using a spectrophotometer (Specord 200, Analytic Jena, Jena, Germany). Superoxide dismutase (SOD; EC 1.15.1.1) activity was estimated according to the method of Giannopolitis and Ries (1977). Enzyme was extracted in $25 \mathrm{mM}$ HEPES, pH 7.8, with 0.1 $\mathrm{mM}$ EDTA and the supernatant was added to the reaction mixture containing $0.1 \mathrm{mM}$ EDTA, $50 \mathrm{mM} \mathrm{Na}_{2} \mathrm{CO}_{3}, \mathrm{pH} 10.2,13 \mathrm{mM}$ methionine, $63 \mu \mathrm{M}$ nitroblue tetrazolium chloride (NBT), and $13 \mu \mathrm{M}$ riboflavin. One unit of SOD was defined as that being contained in the volume of extract that caused a $50 \%$ inhibition of the SOD-inhibitable fraction of the NBT reduction. For determination of catalase (CAT; EC 1.11.1.6) activity, samples were homogenized with $50 \mathrm{mM}$ phosphate buffer, $\mathrm{pH} 7.0$, and assayed spectrophotometrically, by following the degradation of $\mathrm{H}_{2} \mathrm{O}_{2}$ at $240 \mathrm{~nm}$ according to the method of Simon et al. (1974). The reaction medium contained $50 \mathrm{mM}$ phosphate buffer, $\mathrm{pH} 7.0$, and $10 \mathrm{mM} \mathrm{H}_{2} \mathrm{O}_{2}$. All the activities of the enzymes were expressed as $\mathrm{U} / \mathrm{mg}$ (protein).

Genetics and Molecular Research 15 (3): gmr.15038247 
The total antioxidant capacity of non-enzymatic antioxidant was measured using a kit from Nanjing, Jiancheng. The principle of the measurement was based on whether the plant had many antioxidants. If so, then $\mathrm{Fe}^{3+}$ is reduced to $\mathrm{Fe}^{2+}$, which combines morpholine with the Philippine morpholines forming a solid complex substance. The total antioxidant capacity of the leaves can then be determined by its colorimetry.

\section{Leaf soluble protein content, dry weight, and conversion rate}

Leaf soluble protein content was measured according to the Coomassie brilliant blue (G-250) method used by Bradford (1976). Measurements of DW and conversion rates were determined according to the method described by Yang et al. (2002).

\section{Statistical analysis}

All results reported here are the means of replicates. Data were subjected to analysis of variance (ANOVA) using the STATGRAPHICS plus 5.1 statistical software (Statistical Graphics Corp., Princeton, NJ, USA).

\section{RESULTS}

\section{Growth parameters and yield components of japonica rice varieties}

The average yield per ha of Nanjing 44 during 2010-2012 was significantly higher than the control Wuyunjing 7 variety $(24.51 \%$ higher; $\mathrm{P}<0.05)$ (Table 2$)$. The yields of Nanjing 46 and Nanjing 5055 were intermediate between the control and the "super" rice varieties. Nanjing 44, produced the highest yield among the other intermediate- and low-yielding rice varieties, mainly due to the high number of panicles per plant, grains per panicle, and filled-grain percentage.

\begin{tabular}{|c|c|c|c|c|c|c|c|}
\hline Variety & Years & Height (cm) & Panicle number per plant & Grains per panicle & 1000-grain weight $(\mathrm{g})$ & Filled-grain percentage $(\%)$ & Tons/ha \\
\hline \multirow[t]{4}{*}{ Wuyunjing 7 (CK) } & 2010 & $100.12 \pm 3.25^{\mathrm{Aa}}$ & $14.41 \pm 1.51^{\mathrm{Aa}}$ & $128.19 \pm 14.21^{\mathrm{Aa}}$ & $26.14 \pm 1.31^{\mathrm{Aa}}$ & $86.14 \pm 1.57^{\mathrm{Bb}}$ & $10.11 \pm 0.17^{\mathrm{cc}}$ \\
\hline & 2011 & $105.33 \pm 4.04^{\mathrm{Aa}}$ & $15.10 \pm 2.00^{\mathrm{Aa}}$ & $126.33 \pm 13.50^{\mathrm{Aa}}$ & $24.65 \pm 1.20^{\mathrm{Aa}}$ & $87.52 \pm 1.44^{\mathrm{Bb}}$ & $10.50 \pm 0.18^{\mathrm{cc}}$ \\
\hline & 2012 & $104.21 \pm 2.14^{\mathrm{Aa}}$ & $16.54 \pm 1.67^{\mathrm{Aa}}$ & $125.45 \pm 9.71^{\mathrm{Aa}}$ & $23.17 \pm 1.62^{\mathrm{Aa}}$ & $85.34 \pm 2.14^{\mathrm{Bb}}$ & $9.99 \pm 0.15^{\mathrm{Ce}}$ \\
\hline & Average & $103.14 \pm 2.51^{\mathrm{Aa}}$ & $15.35 \pm 1.53^{\mathrm{Aa}}$ & $126.66 \pm 9.15^{\mathrm{Aa}}$ & $24.65 \pm 2.41^{\mathrm{Aa}}$ & $86.33 \pm 1.21^{\mathrm{Bb}}$ & $10.20 \pm 0.41^{\mathrm{Cc}}$ \\
\hline \multirow[t]{4}{*}{ Nanjing 44} & 2010 & $101.12 \pm 3.14^{\mathrm{Aa}}$ & $16.07 \pm 1.47^{\mathrm{Aa}}$ & $136.97 \pm 10.21^{\mathrm{Aa}}$ & $26.04 \pm 1.54^{\mathrm{Aa}}$ & $92.45 \pm 1.21^{\mathrm{Aa}}$ & $11.97 \pm 0.58^{A a}$ \\
\hline & 2011 & $102.14 \pm 4.35^{\mathrm{Aa}}$ & $15.67 \pm 2.08^{\mathrm{Aa}}$ & $135.33 \pm 14.97^{\mathrm{Aa}}$ & $25.88 \pm 2.04^{\mathrm{Aa}}$ & $91.91 \pm 0.94^{\mathrm{Aa}}$ & $12.93 \pm 0.28^{\mathrm{Aa}}$ \\
\hline & 2012 & $101.46 \pm 1.64^{\mathrm{Aa}}$ & $16.47 \pm 1.43^{\mathrm{Aa}}$ & $134.97 \pm 6.47^{\mathrm{Aa}}$ & $25.21 \pm 1.57^{\mathrm{Aa}}$ & $93.54 \pm 1.57^{\mathrm{Aa}}$ & $13.21 \pm 0.47^{\mathrm{Aa}}$ \\
\hline & Average & $101.57 \pm 1.04^{\mathrm{Aa}}$ & $16.07 \pm 1.02^{\mathrm{Aa}}$ & $135.76 \pm 2.14^{\mathrm{Aa}}$ & $25.98 \pm 0.51^{\mathrm{Aa}}$ & $92.62 \pm 0.85^{\mathrm{Aa}}$ & $12.70 \pm 2.34^{\mathrm{Aa}}$ \\
\hline \multirow[t]{4}{*}{ Nanjing 46} & 2010 & $102.14 \pm 3.24^{\mathrm{Aa}}$ & $15.01 \pm 1.32^{\mathrm{Aa}}$ & $128.14 \pm 21.4^{\mathrm{Aa}}$ & $24.57 \pm 1.27^{\mathrm{Aa}}$ & $88.51 \pm 0.81^{\mathrm{Aab}}$ & $11.12 \pm 2.98^{\mathrm{Bb}}$ \\
\hline & 2011 & $105.67 \pm 1.52^{\mathrm{Aa}}$ & $15.33 \pm 1.58^{\mathrm{Aa}}$ & $125.00 \pm 11.51^{\mathrm{Aa}}$ & $24.92 \pm 0.92^{\mathrm{Aa}}$ & $89.53 \pm 0.76^{\mathrm{Aab}}$ & $11.66 \pm 5.54^{\mathrm{Bb}}$ \\
\hline & 2012 & $103.51 \pm 2.54^{\mathrm{Aa}}$ & $15.64 \pm 0.67^{\mathrm{Aa}}$ & $127.89 \pm 3.54^{\mathrm{Aa}}$ & $24.15 \pm 0.56^{\mathrm{Aa}}$ & $87.21 \pm 1.46^{\mathrm{Aab}}$ & $12.11 \pm 3.02^{\mathrm{Bb}}$ \\
\hline & Average & $103.77 \pm 1.35^{\text {Aa }}$ & $15.29 \pm 0.38^{\mathrm{Aa}}$ & $127.01 \pm 3.62^{\mathrm{Aa}}$ & $24.54 \pm 0.31^{\mathrm{Aa}}$ & $89.19 \pm 0.56^{\mathrm{Aab}}$ & $11.63 \pm 1.36^{\mathrm{Bb}}$ \\
\hline \multirow[t]{4}{*}{ Nanjing 5055 } & 2010 & $99.81 \pm 2.47^{\mathrm{Aa}}$ & $15.25 \pm 1.91^{\mathrm{Aa}}$ & $131.14 \pm 14.21^{\mathrm{Aa}}$ & $24.97 \pm 1.47^{\mathrm{Aa}}$ & $90.51 \pm 0.74^{\mathrm{Aab}}$ & $10.54 \pm 2.41^{\mathrm{Bb}}$ \\
\hline & 2011 & $103.33 \pm 3.06^{\mathrm{Aa}}$ & $16.00 \pm 1.73^{\mathrm{Aa}}$ & $130.30 \pm 15.67^{\mathrm{Aa}}$ & $25.23 \pm 2.71^{\mathrm{Aa}}$ & $90.16 \pm 3.73^{\mathrm{Aab}}$ & $11.66 \pm 5.65^{\mathrm{Bb}}$ \\
\hline & 2012 & $101.24 \pm 1.64^{\mathrm{Aa}}$ & $16.24 \pm 1.37^{\mathrm{Aa}}$ & $131.24 \pm 10.49^{\mathrm{Aa}}$ & $25.37 \pm 1.57^{\mathrm{Aa}}$ & $89.47 \pm 2.17^{\mathrm{Aab}}$ & $11.73 \pm 1.32^{\mathrm{Bb}}$ \\
\hline & Average & $101.46 \pm 1.24^{\mathrm{Aa}}$ & $15.83 \pm 1.21^{\mathrm{Aa}}$ & $130.89 \pm 1.34^{\mathrm{Aa}}$ & $25.19 \pm 0.24^{\mathrm{Aa}}$ & $90.05 \pm 0.39^{\mathrm{Aab}}$ & $11.31 \pm 1.34^{\mathrm{Bb}}$ \\
\hline
\end{tabular}

Superscript letters in the same column indicate significant differences (capital letters: $\mathrm{P}<0.01$; lowercase letters: $\mathrm{P}<0.05$ ) among the different rice varieties. CK stands for a control variety with low yield in the present study.

\section{DW of japonica rice varieties after flowering}

Allocation of DW in a plant was the basis for grain yield of rice varieties. Thus, we investigated the changes in DW at the heading stages among the tested rice plants. The DW 
of panicles per plant of Nanjing 44 reached $9.57 \mathrm{~g}$ at $7 \mathrm{DAF}$, which was the heaviest of the four rice varieties. In contrast, the DW of Wuyunjing 7 only reached $5.67 \mathrm{~g}$. That of Nanjing 44 reached $69.63 \mathrm{~g}$ at $42 \mathrm{DAF}$, while that of the control variety only reached $57.19 \mathrm{~g}$ (Table 3). The panicle weights of the other two rice varieties were intermediate between Nanjing 44 and Wuyunjing 7. The grain filling rate of Nanjing 44 in the early DAF was faster and lasted longer than that of the other three rice varieties, which would explain its overall high yield.

Table 3. Dry weights (DW) of the different parts of japonica rice plants from Nanjing, Jiangsu Province, China, in the days after flowering (DAF) in 2010-2012.

\begin{tabular}{|c|c|c|c|c|c|}
\hline Variety & DAF (day) & Stem DW (g) & Panicle DW (g) & Leaf DW (g) & Total DW (g) \\
\hline Wuyunjing $7 \mathrm{CK}$ & \multirow[t]{4}{*}{0} & $54.93 \pm 3.30^{\mathrm{Aa}}$ & $2.67 \pm 0.29^{\mathrm{Gg}}$ & $9.25 \pm 1.62^{\mathrm{Aa}}$ & $66.85 \pm 4.49^{\mathrm{Ff}}$ \\
\hline Nanjing 44 & & $56.06 \pm 3.75^{\mathrm{Aa}}$ & $3.03 \pm 0.60^{\mathrm{Gg}}$ & $10.43 \pm 1.07^{\mathrm{Aa}}$ & $69.52 \pm 4.39^{\mathrm{Ee}}$ \\
\hline Nanjing 46 & & $53.48 \pm 8.59^{\mathrm{Aa}}$ & $3.33 \pm 0.13^{\mathrm{Gg}}$ & $8.13 \pm 0.55^{\mathrm{Bb}}$ & $64.94 \pm 8.35^{\mathrm{Ff}}$ \\
\hline Nanjing 5055 & & $55.25 \pm 0.89^{\mathrm{Aa}}$ & $3.01 \pm 0.31^{\mathrm{Gg}}$ & $8.45 \pm 0.21^{\mathrm{Aa}}$ & $66.71 \pm 0.71^{\mathrm{Ff}}$ \\
\hline Wuyunjing $7 \mathrm{CK}$ & \multirow[t]{4}{*}{7} & $54.21 \pm 3.08^{\mathrm{Aa}}$ & $5.67 \pm 0.09^{\mathrm{Gg}}$ & $6.96 \pm 0.23^{\mathrm{Cc}}$ & $66.84 \pm 3.17^{\mathrm{Ff}}$ \\
\hline Nanjing 44 & & $54.83 \pm 3.66^{\mathrm{Aa}}$ & $9.57 \pm 1.24^{\mathrm{Ff}}$ & $7.69 \pm 0.52^{\mathrm{Bb}}$ & $72.09 \pm 5.35^{\mathrm{Ee}}$ \\
\hline Nanjing 46 & & $56.63 \pm 5.02^{\mathrm{Aa}}$ & $5.83 \pm 2.56^{\mathrm{Gg}}$ & $8.12 \pm 0.65^{\mathrm{Bb}}$ & $70.58 \pm 4.65^{\mathrm{Ee}}$ \\
\hline Nanjing 5055 & & $57.71 \pm 1.55^{\mathrm{Aa}}$ & $7.67 \pm 1.96^{\mathrm{Ff}}$ & $8.33 \pm 0.17^{\mathrm{Bb}}$ & $73.71 \pm 2.25^{\mathrm{Ee}}$ \\
\hline Wuyunjing $7 \mathrm{CK}$ & \multirow[t]{4}{*}{14} & $52.77 \pm 0.79^{\mathrm{Aa}}$ & $11.67 \pm 0.81^{\mathrm{Ff}}$ & $6.67 \pm 0.04^{\mathrm{Cc}}$ & $71.11 \pm 1.43^{\mathrm{Ee}}$ \\
\hline Nanjing 44 & & $54.19 \pm 1.53^{\mathrm{Aa}}$ & $18.33 \pm 3.27^{\mathrm{Ee}}$ & $7.25 \pm 0.26^{\mathrm{Bb}}$ & $79.77 \pm 3.71^{\mathrm{Dd}}$ \\
\hline Nanjing 46 & & $55.67 \pm 1.46^{\mathrm{Aa}}$ & $12.63 \pm 1.11^{\mathrm{Ff}}$ & $6.87 \pm 0.61^{\mathrm{Cc}}$ & $75.17 \pm 3.11^{\mathrm{Ee}}$ \\
\hline Nanjing 5055 & & $55.43 \pm 4.18^{\mathrm{Aa}}$ & $16.52 \pm 0.52^{\mathrm{Ff}}$ & $7.32 \pm 0.89^{\mathrm{Bb}}$ & $79.27 \pm 4.35^{\mathrm{Dd}}$ \\
\hline Wuyunjing 7 CK & \multirow[t]{4}{*}{21} & $51.67 \pm 8.52^{\mathrm{Aa}}$ & $23.83 \pm 1.48^{\mathrm{Ee}}$ & $5.73 \pm 0.91^{\mathrm{Dd}}$ & $81.23 \pm 8.29^{\mathrm{Dd}}$ \\
\hline Nanjing 44 & & $52.37 \pm 1.51^{\mathrm{Aa}}$ & $24.13 \pm 4.35^{\mathrm{Ee}}$ & $6.38 \pm 0.87^{\mathrm{Cc}}$ & $82.88 \pm 4.61^{\mathrm{Dd}}$ \\
\hline Nanjing 46 & & $49.83 \pm 8.37^{\mathrm{Aa}}$ & $15.27 \pm 2.17^{\mathrm{Ff}}$ & $6.28 \pm 1.80^{\mathrm{Cc}}$ & $71.38 \pm 5.19^{\mathrm{Ee}}$ \\
\hline Nanjing 5055 & & $54.33 \pm 4.97^{\mathrm{Aa}}$ & $29.67 \pm 2.53^{\mathrm{Dd}}$ & $6.67 \pm 0.72^{\mathrm{Cc}}$ & $90.67 \pm 4.64^{\mathrm{Cc}}$ \\
\hline Wuyunjing $7 \mathrm{CK}$ & \multirow[t]{4}{*}{28} & $43.73 \pm 3.76^{\mathrm{Bb}}$ & $37.93 \pm 15.76^{\mathrm{Dd}}$ & $4.23 \pm 1.17^{\mathrm{Ee}}$ & $85.89 \pm 12.43^{\mathrm{Cc}}$ \\
\hline Nanjing 44 & & $44.61 \pm 4.48^{\mathrm{Bb}}$ & $44.13 \pm 8.12^{\mathrm{Cc}}$ & $5.63 \pm 0.44^{\mathrm{Dd}}$ & $94.37 \pm 12.23^{\mathrm{Co}}$ \\
\hline Nanjing 46 & & $47.33 \pm 3.23^{\mathrm{Bb}}$ & $30.01 \pm 4.63^{\mathrm{Dd}}$ & $3.34 \pm 0.15^{\mathrm{Ee}}$ & $80.68 \pm 4.25^{\mathrm{Dd}}$ \\
\hline Nanjing 5055 & & $51.68 \pm 4.56^{\mathrm{Aa}}$ & $33.33 \pm 6.82^{\mathrm{Dd}}$ & $5.67 \pm 0.27^{\mathrm{Dd}}$ & $90.68 \pm 9.18^{\mathrm{Cc}}$ \\
\hline Wuyunjing $7 \mathrm{CK}$ & \multirow[t]{4}{*}{35} & $44.33 \pm 4.15^{\mathrm{Bb}}$ & $57.19 \pm 2.08^{\mathrm{Bb}}$ & $2.47 \pm 0.44$ & $103.99 \pm 6.62^{\mathrm{Bb}}$ \\
\hline Nanjing 44 & & $43.43 \pm 2.20^{\mathrm{Bb}}$ & $59.62 \pm 1.19^{\mathrm{Bb}}$ & $3.32 \pm 0.34^{\mathrm{Ee}}$ & $106.37 \pm 3.63^{\mathrm{Bb}}$ \\
\hline Nanjing 46 & & $46.11 \pm 3.04^{\mathrm{Bb}}$ & $58.30 \pm 1.15^{\mathrm{Bb}}$ & $2.93 \pm 0.52^{\mathrm{Ee}}$ & $107.34 \pm 4.28^{\mathrm{Bb}}$ \\
\hline Nanjing 5055 & & $55.32 \pm 4.07^{\mathrm{Aa}}$ & $45.67 \pm 4.05^{\mathrm{Cc}}$ & $3.12 \pm 0.22^{\mathrm{Ee}}$ & $104.11 \pm 7.95^{\mathrm{Bb}}$ \\
\hline Wuyunjing $7 \mathrm{CK}$ & \multirow[t]{4}{*}{42} & $44.55 \pm 2.51^{\mathrm{Bb}}$ & $57.27 \pm 2.60^{\mathrm{Bb}}$ & $2.51 \pm 0.49^{\mathrm{Ee}}$ & $104.33 \pm 1.25^{\mathrm{Bb}}$ \\
\hline Nanjing 44 & & $43.27 \pm 2.35^{\mathrm{Bb}}$ & $69.63 \pm 2.05^{\mathrm{Aa}}$ & $3.18 \pm 0.05^{\mathrm{Ee}}$ & $116.08 \pm 4.14^{\mathrm{Aa}}$ \\
\hline Nanjing 46 & & $46.43 \pm 1.51^{\mathrm{Bb}}$ & $59.23 \pm 1.17^{\mathrm{Bb}}$ & $2.93 \pm 0.60^{\mathrm{Ee}}$ & $108.59 \pm 3.71^{\mathrm{Bb}}$ \\
\hline Nanjing 5055 & & $50.67 \pm 2.03^{\mathrm{Aa}}$ & $62.33 \pm 2.67^{\mathrm{Bb}}$ & $2.83 \pm 0.49^{\mathrm{Ee}}$ & $115.83 \pm 5.30^{\mathrm{Aa}}$ \\
\hline
\end{tabular}

Superscript letters in the same column indicate significant differences (capital letters: $\mathrm{P}<0.01$; lowercase letters: $\mathrm{P}<0.05$ ) among the different rice varieties. CK stands for a control variety with low yield in the present study.

\section{Conversion characteristics of dry matter in different rice plant parts in DAF}

When more of the DW of the source organs, such as leaf or stem, was transferred to the grain, the rice yield increased. This depends of the distribution of the grain. The percentage of dry matter distribution in different plant organs from the first DAF until 42 DAF were continuously measured (Figure 1). The results showed that the DW percentages of the stem and panicle, compared to the whole plant DW in Nanjing 44 were 76.06 and $13.28 \%$, respectively, at $7 \mathrm{DAF}$. In contrast, those of Wuyunjing 7 were 81.10 and $8.48 \%$, respectively. The percentages of the stem and panicle DW compared to the whole plant DW in Nanjing 44 were also larger than the two intermediate yield rice varieties. Furthermore, the percentage of panicle weight as compared to the whole plant in Nanjing 44 was the highest of all tested rice plants in this study. This indicates that the dry matter of Nanjing 44 is quickly transferred to

Genetics and Molecular Research 15 (3): gmr.15038247 
the grain at the start of the grouting. At $42 \mathrm{DAF}$, the panicle weight percentage per total plant weight of Nanjing 44 was $59.97 \%$ and higher than those of Nanjing 46 and Nanjing 5055, while that of Wuyunjing 7 was $54.89 \%$. Throughout the grain filling period, the dry matter of Nanjing 44 always had a high proportion to grain, even in the later-grain-filling stages. The conversion rate of the material in the stems, such as percentage of the exported matter in stemsheath in Nanjing 44 was $20.81 \%$. This was higher than that of Wuyunjing 7 (18.90\%) (Table 4). Taken together, the results indicate that Nanjing 44 had the highest capability of exporting or transferring the dry matter from its stem to grains.

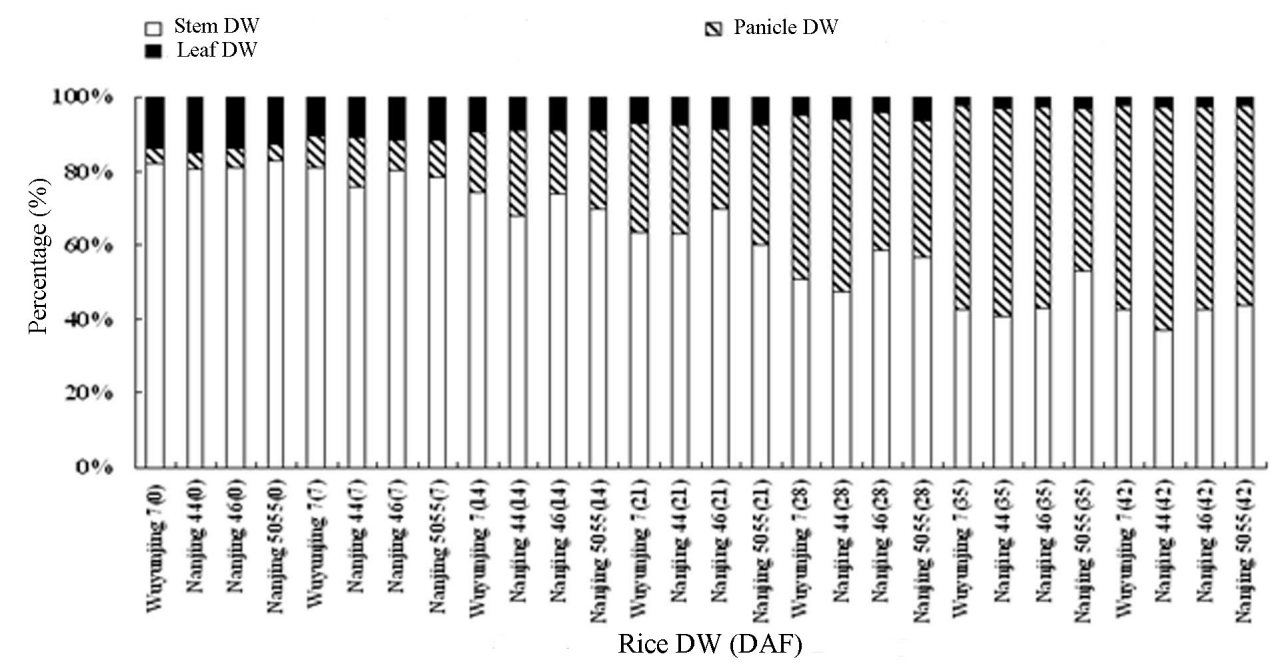

Figure 1. Percentage of dry matter of japonica rice in days after flowering (DAF) in Nanjing, Jiangsu Province, China, 2010-2012. DW = dry weight.

Table 4. Transport of dry matter of different materials.

\begin{tabular}{l|c|c|c|c}
\hline Variety & EPMSS (\%) & TPMSS (\%) & EPML (\%) & TPML (\%) \\
\hline Wuyunjing 7 (CK) & $18.90 \pm 1.20^{\mathrm{b}}$ & $19.01 \pm 1.20^{\mathrm{a}}$ & $72.86 \pm 2.10^{\mathrm{a}}$ & $12.34 \pm 1.10^{\mathrm{a}}$ \\
\hline Nanjing 44 & $22.81 \pm 1.30^{\mathrm{a}}$ & $19.20 \pm 1.10^{\mathrm{a}}$ & $69.54 \pm 2.60^{\mathrm{a}}$ & $10.90 \pm 1.20^{\mathrm{a}}$ \\
\hline Nanjing 46 & $13.18 \pm 1.10^{\mathrm{c}}$ & $17.22 \pm 1.00^{\mathrm{a}}$ & $67.91 \pm 3.20^{\mathrm{a}}$ & $13.43 \pm 1.40^{\mathrm{a}}$ \\
\hline Nanjing 5055 & $8.29 \pm 1.10^{\mathrm{d}}$ & $8.08 \pm 1.00^{\mathrm{b}}$ & $66.51 \pm 2.30^{\mathrm{a}}$ & $9.47 \pm 1.10^{\mathrm{a}}$ \\
\hline
\end{tabular}

EPMSS: percentage of the export mater in stem-sheath; TPMSS: percentage of the transformation matter in stemsheath; EPML: percentage of the export mater in leaf; TPML: percentage of the transformation matter in leaf. Superscript letters in the same column indicate significant differences (capital letters: $\mathrm{P}<0.01$; lowercase letters: $\mathrm{P}<0.05$ ) among the different rice varieties. CK stands for a control variety with low yield in the present study.

\section{Diurnal variation of photosynthetic materials before and after flowering}

More than $80 \%$ of the photosynthetic products in the leaves after flowering are converted to yield and the flag leaves are responsible for more than $50 \%$ of the overall photosynthesis of the plant (Li et al., 2011). Therefore, the $P_{n}$ was measured at different times of day, before and after flowering (Figure 2), and so was the air temperature during those days (Figure 3). The minimum temperature was $10^{\circ} \mathrm{C}$, the maximum temperature was $36^{\circ} \mathrm{C}$, and 
the average temperature was $25.28^{\circ} \mathrm{C}$ (Figure 3). The $P_{n}$ of the tested materials was usually highest at 9:00 am, with a decline at 13:00 pm, and a certain degree of recovery by 16:00 $\mathrm{pm}$. It exhibited a typical diurnal variation observed in $\mathrm{C}_{3}$ plant photosynthesis, which use $\mathrm{C}_{3}$ photosynthesis depending on whether the primary photosynthesis product contains three carbons. We found that the $P_{n}$ of Nanjing 44 was still the highest of the four tested varieties at 12 days before flowering. The $P_{\mathrm{n}}$ of Nanjing 44 at 9:00 am was as high as $25.4 \mu \mathrm{mol} \cdot \mathrm{m}^{-2} \cdot \mathrm{s}^{-1}$, which was $10.00 \%$ higher than the control variety, Wuyunjing 7, on 12 DAF. The $P_{n}$ of Nanjing 44 decreased less at noon during the DAF, as compared with the other three rice varieties, indicating that the photoinhibition of photosynthesis in the leaves of Nanjing 44 at noon was not as obvious. Thus, during the filling stage, the flag leaf of Nanjing 44 still maintained a high-photosynthetic function (Figure 2), which could provide more photosynthetic products to the leaves.

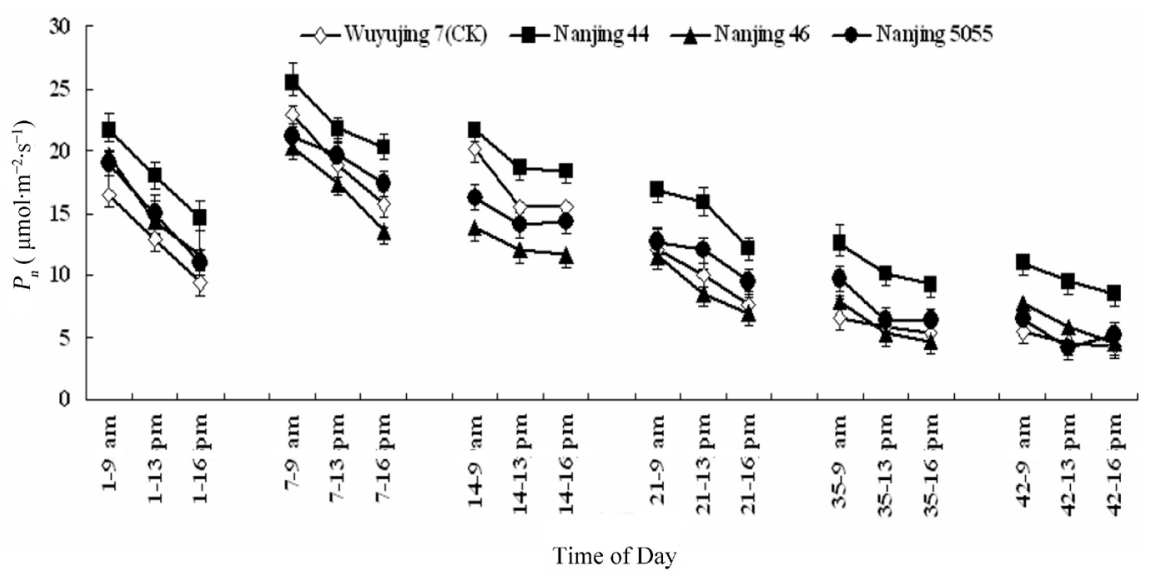

Figure 2. Diurnal variation of $P_{n}$ in different varieties in Nanjing, Jiangsu Province, China, 2010-2012. Vertical bars represent $\mathrm{SD}, \mathrm{N}=5$.

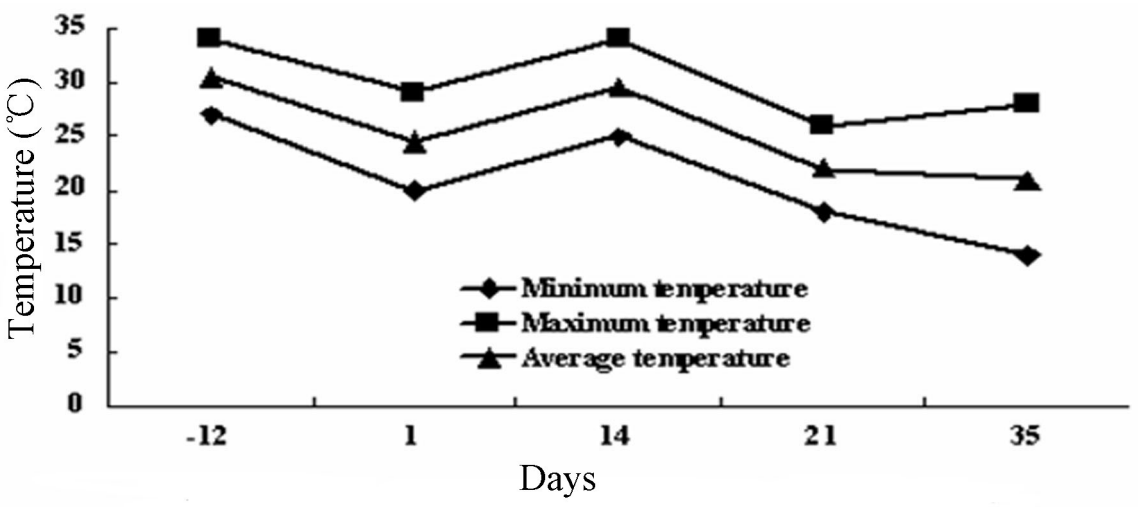

Figure 3. Daily maximum, minimum, and average air temperatures during the rice growing season in Nanjing, Jiangsu Province, China, 2010-2012. The temperature variation was measure 12 days before flowering (-12) and at $1,14,21$, and 35 days after flowering. Vertical bars represent $\mathrm{SD}, \mathrm{N}=5$. 


\section{Daily distribution of leaf light for the tested rice varieties}

Figure 4 shows how the Chl contents changes post-flowering in the tested rice varieties. It was obvious that the $\mathrm{Chl}$ content began to decrease by $21 \mathrm{DAF}$. As compared with the Chl contents in the other three rice varieties, Nanjing 44 showed the lowest decrease in Chl contents in all DAF. By photooxidation identification, Nanjing 44 was identified as type 1 , indicating that it is tolerant to photooxidation stress, and was of the same type as the control variety, Wuyunjing 7 (Table 5). Prior to the photooxidation treatments, the Chl content of Nanjing 44 was $25.30 \%$ higher than that of Wuyunjing 7. After the photooxidation treatment, Nanjing 44 was still $14.17 \%$ higher than Wuyunjing 7 , in terms of Chl content. The leaf color grades of the intermediate rice varieties revealed that they were more sensitive to photooxidation than Nanjing 44. The Nanjing 44 photooxidation identification results are consistent with the observed lower decrease of Chl content at $42 \mathrm{DAF}$.

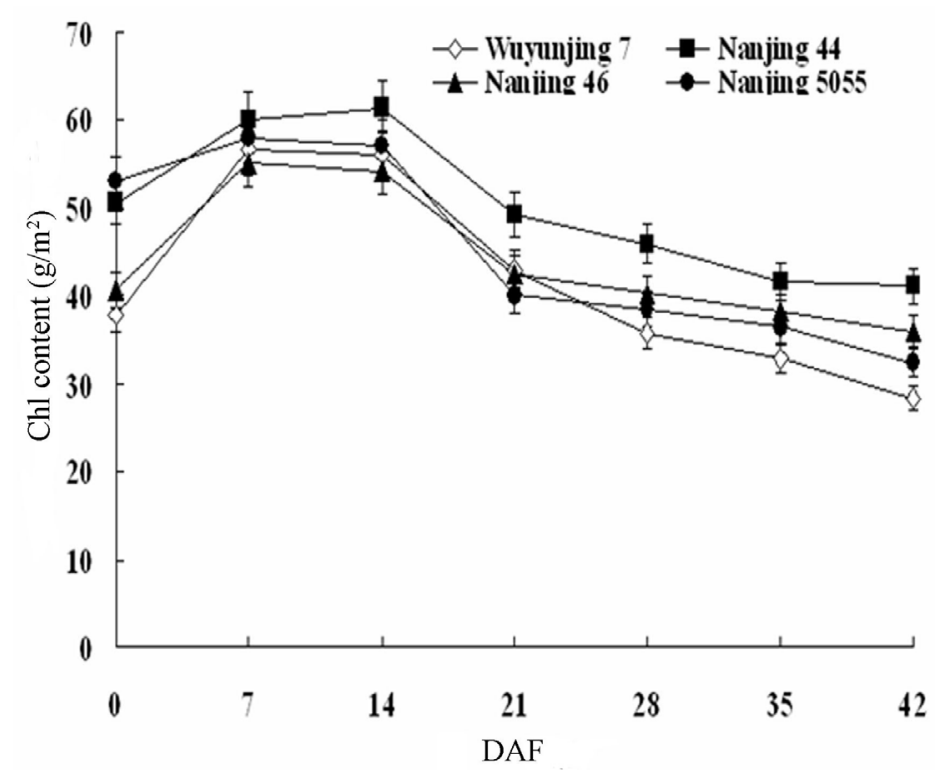

Figure 4. Changes in the chlorophyll (Chl) content at days after flowering (DAF) in the different rice varieties under field conditions in Nanjing, Jiangsu Province, China, 2010-2012. Vertical bars represent SD, N = 5.

Table 5. Effects of photooxidation treatment on chlorophyll (Chl) content in rice cultivars.

\begin{tabular}{|c|c|c|c|c|c|c|c|c|c|c|c|c|c|}
\hline \multirow[t]{2}{*}{ Variety } & \multicolumn{3}{|c|}{$\operatorname{Chl} a$} & \multicolumn{3}{|c|}{$\mathrm{Chl} b$} & \multicolumn{3}{|c|}{ Total Chl content } & \multicolumn{3}{|c|}{$\mathrm{Chl} a / \mathrm{Chl} b$} & \multirow{2}{*}{$\begin{array}{c}\text { Photooxidation } \\
\text { color rating }\end{array}$} \\
\hline & Before (B) & After (A) & $\mathrm{A} / \mathrm{B}(\%)$ & Before (B) & After (A) & $\mathrm{A} / \mathrm{B}(\%)$ & Before (B) & After (A) & $\mathrm{AB}(\%)$ & Before (B) & After (A) & $\mathrm{A} / \mathrm{B}(\%)$ & \\
\hline Wuyunjing 7 (CK) & $\frac{\left(\mathrm{g} \mathrm{m}^{3}\right)}{37.8 \pm 0.6^{\mathrm{Bn}}}$ & $\frac{\left(\mathrm{g} \mathrm{m}^{2}\right)}{32.1 \pm 0.3^{\lambda \mathrm{n}}}$ & $84.00 \pm 1.00^{12 x}$ & $\frac{\left(\mathrm{g} / \mathrm{g}^{2}\right)}{14.8 \pm 0.3^{155}}$ & $\frac{\left(\mathrm{gm}^{2}\right)^{10 \mathrm{~A}}}{10.8 \pm 01^{1 \mathrm{~A}}}$ & $73.00 \pm 1.00^{0 / n}$ & $\frac{\left(\mathrm{gm}^{2}\right)}{52.6 \pm 0.9^{106}}$ & \begin{tabular}{|l|}
$(g \mathrm{gm})$ \\
$42.9 \pm 0.4^{40}$
\end{tabular} & $82.00 \pm 2.00^{\lambda A}$ & $\frac{\left(\mathrm{gm}^{2}\right)^{1 \mathrm{~s}}}{25.6 \pm 0.3^{\mathrm{s}}}$ & $\frac{\left(\mathrm{gm}^{2}\right)^{29.7}}{29 \pm 0.03^{3 n}}$ & $116.0 \pm 1.00^{\text {Xn }}$ & 2 \\
\hline Nanjing 44 & $50.6 \pm 0.5^{\lambda^{2}}$ & $37.4 \pm 0.2^{\text {An }}$ & $73.00 \pm 1.00^{1 \mathrm{Hb}}$ & $20.2 \pm 0.2^{A_{A}}$ & $12.5 \pm 0.02^{2 n}$ & $62.00 \pm 1.00^{\mathrm{DB}}$ & $70.8 \pm 0.7^{\wedge \mathrm{n}}$ & $49.9 \pm 0.2^{\Lambda A}$ & $70.00 \pm 1.00^{\text {Is }}$ & $25.0 \pm 0.1^{\lambda \text { Ana }}$ & $30.0 \pm 0.04^{4 n}$ & $120.0 \pm 2.00^{\wedge \mathrm{n}}$ & 1 \\
\hline $\begin{array}{l}\text { Nanjing } 46 \\
\end{array}$ & $40.7 \pm 0.15^{\mathrm{Bb}}$ & $21.3 \pm 0.3^{\mathrm{sh}}$ & $52.00 \pm 1.00^{\mathrm{cc}}$ & $16.9 \pm 0.2^{\mathrm{sth}}$ & $8.8 \pm 0.1^{\mathrm{pb}}$ & $52.00 \pm 2.00^{\mathrm{ccc}}$ & $57.6 \pm 0.17^{\mathrm{pb}}$ & $30.2 \pm 0.4^{\mathrm{Cc}^{\mathrm{C}}}$ & \begin{tabular}{|c|}
$52.00 \pm 1.00^{\mathrm{CE}}$ \\
\end{tabular} & $24.1 \pm 0.6^{\Lambda A}$ & $24.3 \pm 0.01^{159}$ & $100.1 \pm 3.00^{\mathrm{Bb}}$ & 3 \\
\hline Nanjing 5055 & $53.2 \pm 0.2^{\lambda \mathrm{A}}$ & $17.5 \pm 0.1^{\mathrm{Bh}}$ & $33.00 \pm 1.00^{\mathrm{DAd}}$ & $21.4 \pm 0.2^{\Lambda A}$ & $8.5 \pm 0.2^{\mathrm{Bb}}$ & $39.00 \pm 1.00^{0 \mathrm{Dd}}$ & $74.7 \pm 0.3^{\Lambda \mathrm{n}}$ & $26.0 \pm 0.3^{\mathrm{Dd}}$ & $35.00 \pm 1.00^{\mathrm{Dd}}$ & $24.8 \pm 0.1^{\Lambda A}$ & $20.8 \pm 0.04^{4 c}$ & $84.00 \pm 1.00^{\mathrm{CC}}$ & 3 \\
\hline
\end{tabular}

Observed color rating of photooxidation: 1: whole leaf green; 2 : tip yellowish; 3: 1/3 yellowish; 4: 1/2 yellowish; 5: whole leaf yellowish. The values given are mean of three replications \pm SE. Superscript letters in the same column indicate significant differences (capital letters: $\mathrm{P}<0.01$; lowercase letters: $\mathrm{P}<0.05$ ) among the different rice varieties. CK stands for a control variety with low yield in the present study.

Genetics and Molecular Research 15 (3): gmr.15038247 


\section{Antioxidant enzyme activity and total non-enzymatic system antioxidant capacity}

On 35 DAF, the MDA content of Nanjing 44 was $51.91 \%$ lower than that of the control (Figure 5A). As compared with the other rice varieties, the SOD, peroxidase (POD), and CAT activities in the Nanjing 44 flag leaf were also the highest. Compared to Wuyunjing 7, the SOD (Figure 5B), POD (Figure 5C), and CAT (Figure 5D) activities in Nanjing 44 were $7.03,11.56$ and $8.54 \%$ higher, respectively. Furthermore, the total antioxidant capacity of the non-enzymatic system in Nanjing 44 (Figure 5E) was $11.28 \%$ higher than that of the control variety. Likewise, the soluble protein of the flag leaves in Nanjing 44 was 5.1\% higher than Wuyunjing 7 (Figure 5F). The values observed in the intermediate rice varieties were in between Nanjing 44 and Wuyunjing 7.
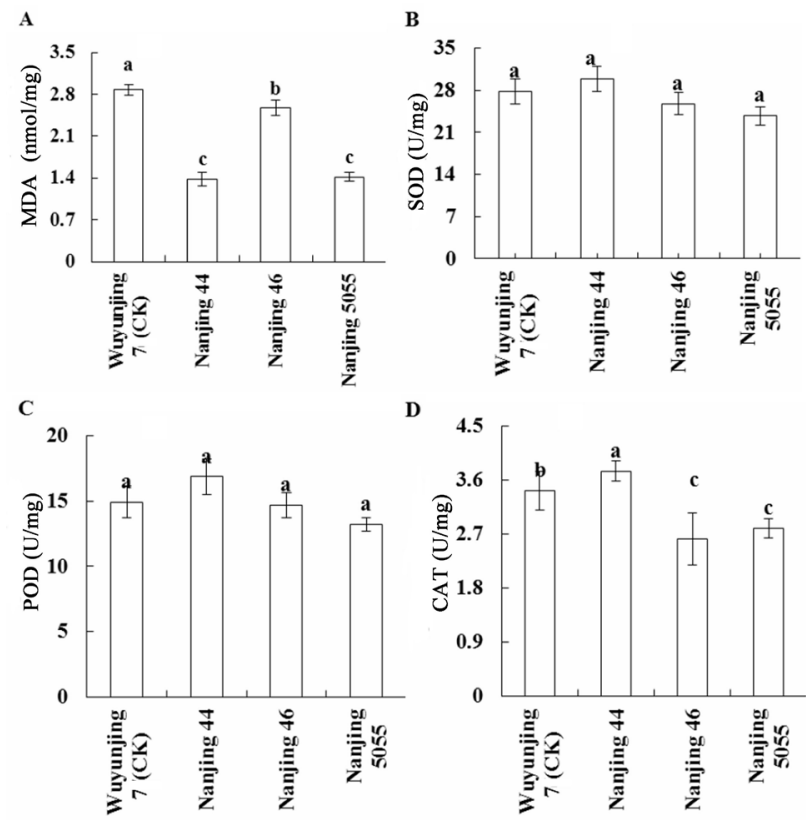

D 4.5
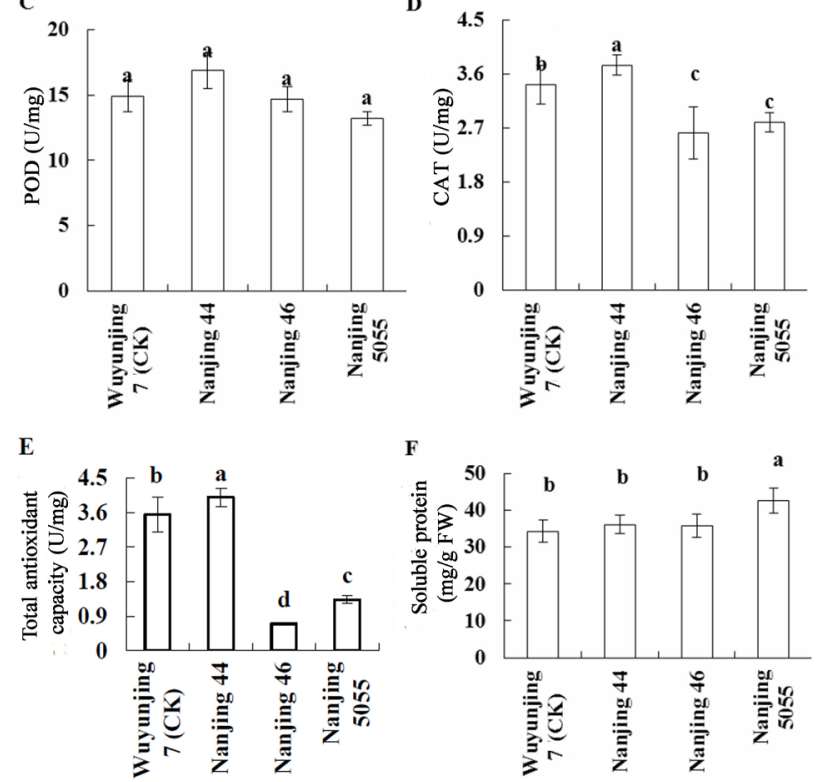

Figure 5. Antioxidant enzyme activities, total antioxidant capacity, and soluble protein of different rice varieties in Nanjing, Jiangsu Province, China, 2010-2012. Vertical bars represent SD, N = 5. A. MDA (malondialdehyde) content; B. SOD (superoxidase dismutase) activity; C. POD (peroxidase) activity; D. CAT (catalase) activity; E. total antioxidant capacity with non-enzymes; F. soluble protein content in flag leaves. $\mathrm{CK}=$ control variety. Letters above the bars indicate significant differences $(\mathrm{P}<0.05)$.

Genetics and Molecular Research 15 (3): gmr.15038247 


\section{Correlations between photosynthetic parameters and yield components}

The correlation coefficient between panicles per plant and plant height was $0.70(\mathrm{P}<$ $0.05)$. The correlation coefficients between plant height and spikelet per plant or plant yield were 0.52 and 0.55 , respectively $(\mathrm{P}<0.05)$. The correlation coefficients between panicles per plant and the total spikelet per plant or yield per plant were 0.89 and 0.91 , respectively $(\mathrm{P}<$ $0.01)$. The coefficient between grains per panicle and seed setting rate was $0.63(\mathrm{P}<0.05)$, and those between grain weight per plant and panicles per plant or spikelet per plant were 0.55 and 0.78 , respectively $(\mathrm{P}<0.05)$. This indicates that the sink, including panicles per plant and spikelet per plant, were the main factors that determined the rice yield. The correlation coefficients between $P_{n}$ at 13:00 pm on 21 DAF and the grains per panicle or spikes per plant were 0.61 and 0.59 , respectively $(\mathrm{P}<0.05)$. The correlation coefficients between $P_{n}$ at 13:00 $\mathrm{pm}$ on $21 \mathrm{DAF}$ and seed setting rate, 1000-grain weight or grain weight of plant were 0.74 , 0.79 , and 0.68 , respectively $(\mathrm{P}<0.01)$. The photosynthetic capability of flag leaves in rice varieties was the key trait determining the filling of grains, including the weight of the panicle and the flow rate of photosynthetic products for high yield, in the given plant type.

\section{DISCUSSION}

China's research on "super" rice varieties has incorporated the use of both morphological improvement and heterosis as technological routes. Morphological improvements involve shaping the ideal plant, which will produce an excellent plant type that can thrive under different environment conditions. Yang et al. (2000) have shown that the agronomic and physiological traits, as well as the yield of japonica rice, have been significantly improved. However, most results were from "super" hybrids (Cheng et al., 2007). In fact, many "super" hybrids often encounter adversity and exhibited lower seed setting rate, seriously affecting the performance of their yield potential (Yang et al., 2002), while high-yielding japonica can be adapted to a variety of conditions and has shown high seed setting rate (Jiao and Li, 2001; Zhang et al., 2009b; Yang and Zhang, 2010). It can be observed that increasing the intrinsic physiological functions of the rice, to improve the adaptability to adverse conditions, would be an important way to produce higher yields in rice.

In this paper, as a "super" japonica rice variety, Nanjing 44, from the Jiangsu Province of China, has enough panicles and longer, erect, thick narrow leaves, quite similar to the other three rice varieties tested. Furthermore, Nanjing 44 was found to have a strong photosynthetic physiological function at the single leaf level, which resulted in more photosynthetic products in the leaves and a faster transfer from stem to grain. In addition, the "super" rice variety Nanjing 44 had a more stable Chl content and was more tolerant to photooxidation. This allows it to thrive in bad environments at the later DAF (42 DAF). The higher activities of the antioxidative enzymes and the non-enzyme antioxidative capability in Nanjing 44 would also have aided the avoidance of the damaging photooxidative stress at the later DAF. The results were rather similar to those found in the hybrid rice variety, another "super" rice Liangyoupeiju (Zhang et al., 2010), and this response was also consistent with that induced by cold in japonica rice varieties (Bonnecarrère et al., 2011). The observed good plant type and the photosynthetic capacity of a single rice plant leaf can be used for screening, which would be a noteworthy breeding strategy.

In 1928, Mason and Maskell developed the concept of the source, sink and source-

Genetics and Molecular Research 15 (3): gmr.15038247 
sink relationship. In recent decades, much research has focused on determining the source, sink and source-sink relationship (Venkateswarlu and Visperas, 1987; Yuan et al., 2005). In addition, identification of different types of species, including the source-limited type, sinklimited type, and those with optimized control of the source-sink relationship, has been performed (Lan et al., 2007). Murchie et al. (2002) also posed the question whether there were associations between grain-filling rate and photosynthesis in the flag leaves of fieldgrown rice. In field experiments, they found that rubisco accumulated to a level in excess of photosynthetic requirements, serving as a store of nitrogen for grain filling (Murchie et al., 2002). The photosynthesis efficiency in rice grain yield depends on the ability of material production (source), grain composition conditions (sink), and the operation and distribution of the photosynthetic assimilate (flow). The rate of operation and distribution of photosynthetic products is one of the key factors that affects the efficiency of grain growth and grain yield. During the rice grain formation stage, if the photosynthetic products quickly flow to the seed, it is conducive to the formation of high yield. Zhang et al. (1995) proposed that the best period for the accumulation of dry matter in super-yielding rice varieties was prior to the heading stage, and that the rate of energy accumulation in the rice was also higher at that period (Lin et al., 2006). A study of the rice leaf age model found that, although the stem and sheath of the low-yielding varieties had higher output, the yield was still not high because of a lower dry matter accumulation from leaf (stem) to grain during the heading to maturity stages (Yang et al., 2013). Hence, it seems that the grain increase is also related to the transfer of dry matter from stem to grain. Therefore, views on the accumulation of starch dependency and the heading of high-yield rice varieties were put forward. These views emphasized the importance of the leaf system, stem reserves, and production at the later growth stages of rice, especially the flowering stage (Ling et al., 1993). Murchie et al. (2002) reported that a rapid grain-filling phase occurred approximately 10 days after flowering in most varieties. But the results found in the present study suggest that the photosynthetic apparatus in the high-yielding Nanjing 44 remained stable until $21 \mathrm{DAF}$, which is also important to satisfy the longer grain-filling time.

In this paper, we found that the high yield capability of the "super" rice Nanjing 44, was related to three obvious advantages in the photosynthetic function of the leaves during the late developmental stage. First, the highest photosynthetic characteristics of jointing and booting not only form a strong source (leaf) and a large sink (spike), but also allow filling of the grains as soon as possible. Second, the stable $P_{n}$ of the flag leaf during the heading stage and throughout the whole day, especially under the high light intensity and air temperatures at noon, indicated that the external environmental conditions had less influence on the storage and conversion of photosynthetic products to grain. Furthermore, the higher antioxidant capabilities at the late filling stages (42 DAF) also protected the photosynthetic apparatus of the flag leaves, which allowed a longer filling period. For example, the endogenous reactive oxygen scavenging enzymes, such as SOD and POD, had higher induced activity levels in the flag leaves. Third, the conversion efficiency of photosynthetic products from stem to grain in Nanjing 44 was relatively high, thereby ensuring that the accumulation of photosynthetic products was transformed smoothly to the grain of the "super" rice variety during the 42 DAF.

"Super" rice research is an important topic in the world, and, as Yuan (2001) proposed, "super" rice production targets should vary with age, the eco-regions, and planting season. The standards should also change according to these variables (Peng et al., 2009). Based on good plant types and good photosynthetic physical advantages, the high and "super" high yield rice varieties are achieved by increasing the source, accelerating the flow, the expansion of the 
sink (leaf), and other steps. The problems with the yields of some current varieties have been found to be due to environmental stresses in different regions, and research on rice with broad adaptability and increased tolerance to stress will be necessary.

\section{Conflicts of interest}

The authors declare no conflict of interest.

\section{ACKNOWLEDGMENTS}

Research supported by grants from the National Natural Science Foundation of China (\#31371554), the Agricultural Science and Technology Innovation Fund of Jiangsu Province in China [\#cx(13)5002], the Natural Science Foundation of Jiangsu Province (\#BK20130708), and the Provincial Key Laboratory of Agrobiology in Jiangsu Academy of Agricultural Sciences (\#49114042015Z008). The authors express their great thanks to anonymous reviewers and editorial staff for their time and attention.

\section{REFERENCES}

Bonnecarrère V, Borsani O, Díaz P, Capdevielle F, et al. (2011). Response to photoxidative stress induced by cold in japonica rice is genotype dependent. Plant Sci. 180: 726-732. http://dx.doi.org/10.1016/j.plantsci.2011.01.023

Bradford MM (1976). A rapid and sensitive method for the quantitation of microgram quantities of protein utilizing the principle of protein-dye binding. Anal. Biochem. 72: 248-254. http://dx.doi.org/10.1016/0003-2697(76)90527-3

Cheng SH, Zhuang JY, Fan YY, Du JH, et al. (2007). Progress in research and development on hybrid rice: a superdomesticate in China. Ann. Bot. 100: 959-966. http://dx.doi.org/10.1093/aob/mcm121

Evans LT (1993). Crop evolution adaptation and yield. Cambridge University Press, Cambridge, 498.

Giannopolitis CN and Ries SK (1977). Superoxide dismutases: I. Occurrence in higher plants. Plant Physiol. 59: 309-314. http://dx.doi.org/10.1104/pp.59.2.309

Habibi G, Hajiboland R and Dehghan G (2010). Contrastive response of Phlomis tuberosa to salinity and UV radiation stresses. Acta Biol. Szeged. 54: 37-43.

Jiao DM and Li X (2001). Cultivar differences in photosynthetic tolerance to photooxidation and shading in rice (Oryza sativa L.). Photosynthetica 39: 167-175. http://dx.doi.org/10.1023/A:1013758504857

Kato M, Kobayashi K, Ogiso E and Yokoo M (2004). Photosynthesis and dry-matter production during ripening stage in a female-sterile line of rice. Plant Prod. Sci. 7: 184-188. http://dx.doi.org/10.1626/pps.7.184

Lan HG, Du CY and Liu MH (2007). Advance of study on source and sink relation of rice. North Rice 1: 13-18.

Li DQ, Tang QY, Zhai YG, Qin JQ, et al. (2010a). Effect of different nitrogen management patterns on grain yield and radiation use efficiency of middle-season indica super hybrid rice. J. Hunan Agric. Univ. (Nat. Sci.) 5: 489-494. (in Chinese with English abstract).

Li JG and Han Y (2010). Studies on yield and source-sink characteristics of japonica super rice varieties in Liaoning Province. J. Jilin Agric. Sci 35: 1-4.

Li X, Sun ZW, Lu CG, Ren CG, et al. (2010b). Mass screening and cluster analysis for tolerance to stress of hybrid rice variety under field conditions. Chin. J. Eco Agric. 18: 528-534. http://dx.doi.org/10.3724/SP.J.1011.2010.00528

Li X, Cao K, Wang C and Sun ZW (2010c). Variation of photosynthetic tolerance of rice cultivars (Oryza sativa L.) to chilling temperature in the light. Afr. J. Biotechnol. 9: 1325-1337.

Li X, Sun ZW, Jin L, Han L, et al. (2011). High/low nitrogen adapted hybrid rice cultivars and their physiological responses. Afr. J. Biotechnol. 10: 3731-3738.

Lichtenthaler HK and Wellburn AR (1983). Determinations of total carotenoids and chlorophylls $a$ and $b$ of leaf extracts in different solvents. Biochem. Soc. Trans. 11: 591-592. http://dx.doi.org/10.1042/bst0110591

Lin R, Liang Y, Cai B, Chen W, et al. (2006). Energy accumulation and caloric value in yield-forming process of different rice cultivars. Ying Yong Sheng Tai Xue Bao 17: 1899-1904.

Ling QH, Zhang HC, Cai JZ, Su ZF, et al. (1993). Rice yield and optimal control of population quality. Agric. Sci. China 6: 1-11.

Genetics and Molecular Research 15 (3): gmr.15038247 
Mason ML and Maskell EJ (1928). Studies on the transport of carbohydrates in the cotton plant. II. The factors determining the rate and the direction of movement of sugars. Ann. Bot. 42: 571-636.

Mishra A and Salokhe VM (2008). Seedling characteristics and the early growth of transplanted rice under different water regimes. Exp. Agric. 44: 365-383. http://dx.doi.org/10.1017/S0014479708006388

Murchie EH, Yang J, Hubbart S, Horton P, et al. (2002). Are there associations between grain-filling rate and photosynthesis in the flag leaves of field-grown rice? J. Exp. Bot. 53: 2217-2224. http://dx.doi.org/10.1093/jxb/erf064

Normile D (2008). Agricultural research. Reinventing rice to feed the world. Science 321: 330-333. http://dx.doi. org/10.1126/science.321.5887.330

Peng S, Cassman KG, Virmani SS, Sheehy J, et al. (1999). Yield potential trends of tropical rice since the release of IR8 and the challenge of increasing rice yield potential. Crop Sci. 39: 1552-1559. http://dx.doi.org/10.2135/ cropsci1999.3961552x

Peng S, Khush GS, Virk P, Tang Q, et al. (2008). Progress in ideotype breeding to increase rice yield potential. Field Crops Res. 108: 32-38. http://dx.doi.org/10.1016/j.fcr.2008.04.001

Peng XM, Zhang XP, Zhou WX, Yi ZX, et al. (2009). Research progress of super rice and its prospect on cultivation research in China. Crops Res. 23: 1-6.

San-oh Y, Sugiyama T, Yoshita D, Ookawa T, et al. (2006). The effect of planting pattern on the rate of photosynthesis and related processes during ripening in rice plants. Field Crops Res. 96: 113-124. http://dx.doi.org/10.1016/j. fcr.2005.06.002

Simon LM, Fatrai Z, Jonas DE and Matkovics B (1974). Study of peroxide metabolism enzymes during the development of Phaseolus vulgaris. Biochem. Physiol. Pflanz. 166: 387-392.

Sofo A, Dichio B, Xiloyannis C and Masia A (2004). Effects of different irradiance levels on some antioxidant enzymes and on malondialdehyde content during rewatering in olive tree. Plant Sci. 166: 293-302. http://dx.doi.org/10.1016/j. plantsci.2003.09.018

Tester M and Langridge P (2010). Breeding technologies to increase crop production in a changing world. Science 327 : 818-822. http://dx.doi.org/10.1126/science. 1183700

Venkateswarlu B and Visperas RM (1987). Source-sink relationships in crop plants. IRRI Res. Paper Series (Philippines) 125: 1-19.

Wu GC, Zhang HC, Qian YF, Li DJ, et al. (2010). Rule of grain yield components from high yield to super high yield and the characters of super-high yielding japonica super rice. China Agric. Sci. 43: 266-276.

Xiao JH, Grandillo S, Ahn SN, McCouch SR, et al. (1996). Genes from wild rice improve yield. Nature 384: 223-224. http://dx.doi.org/10.1038/384223a0

Yang CD, Li GH, Li GY, Xia QM, et al. (2013). Establishment of leaf age model of rice varieties at different altitude environments in Yunnan Province, China. Xi Nan Nong Ye Xue Bao 26: 1372-1377.

Yang J and Zhang J (2010). Grain-filling problem in 'super' rice. J. Exp. Bot. 61: 1-5. http://dx.doi.org/10.1093/jxb/erp348

Yang J, Peng S, Visperas RM, Sanico AL, et al. (2000). Grain filling pattern and cytokinin content in the grains and roots of rice plants. Plant Growth Regul. 30: 261-270. http://dx.doi.org/10.1023/A:1006356125418

Yang J, Peng S, Zhang Z, Wang Z, et al. (2002). Grain and dry matter yields and partitioning of assimilates in japonical indica hybrid rice. Crop Sci. 42: 766-772. http://dx.doi.org/10.2135/cropsci2002.0766

Yuan JC, Ding Z, Ye SZ, Yao FJ, et al. (2005). Effect of source-sink relation on grain filling properties of rice. Xi Nan Nong Ye Xue Bao 18: 15-19.

Yuan L (2001). Breeding of super hybrid rice. In: Rice research for food security and poverty alleviation (Peng S and Hardy B, eds.). International Rice Research Institute, Los Baños, 143-149.

Zhang H, Xue YG, Wang ZQ, Yang JC, et al. (2009a). Morphological and physiological traits of roots and their relationships with shoot growth in "super" rice. Field Crops Res. 113: 31-40. http://dx.doi.org/10.1016/j.fcr.2009.04.004

Zhang H, Li H, Yuan L, Wang Z, et al. (2012). Post-anthesis alternate wetting and moderate soil drying enhances activities of key enzymes in sucrose-to-starch conversion in inferior spikelets of rice. J. Exp. Bot. 63: 215-227. http://dx.doi. org/10.1093/jxb/err263

Zhang HS, Yan TZ and Zuo TM (1995). Japonica hybrid rice and conventional rice production and nutritional properties of the material comparison. Xi Nan Nong Ye Xue Bao 4: 11-16.

Zhang MP, Zhang CJ, Yu GH, Jiang YZ, et al. (2010). Changes in chloroplast ultrastructure, fatty acid components of thylakoid membrane and chlorophyll $a$ fluorescence transient in flag leaves of a super-high-yield hybrid rice and its parents during the reproductive stage. J. Plant Physiol. 167: 277-285. http://dx.doi.org/10.1016/j.jplph.2009.09.017

Zhang Q (2007). Strategies for developing green super rice. Proc. Natl. Acad. Sci. USA 104: 16402-16409. http://dx.doi. org/10.1073/pnas.0708013104

Zhang YB, Tang QY, Zou YB, Li DQ, et al. (2009b). Yield potential and radiation use efficiency of "super" hybrid rice grown under subtropical conditions. Field Crops Res. 114: 91-98. http://dx.doi.org/10.1016/j.fcr.2009.07.008

Genetics and Molecular Research 15 (3): gmr.15038247 